\title{
The relationships among the five key foreign tourist markets in the Greater Mekong Sub-region
}

\section{Sakkarin Nonthapot ${ }^{\mathrm{a}^{*}}$}

\begin{tabular}{l}
${ }^{a}$ Khon Kaen University, Nong Khai \\
\hline C H R O N I C L E \\
\hline Article history: \\
Received June 19, 2020 \\
Received in revised format: \\
June 19, 2020 \\
Accepted August 302020 \\
Available online \\
September 1, 2020 \\
\hline Keywords: \\
GMS \\
Market relations \\
Regional tourism \\
Tourist market
\end{tabular}

\section{Introduction}

The Greater Mekong Sub-Region (GMS) was formed in 1992 (Nonthapot, 2014 ) with the cooperation of the six member countries: Cambodia, Lao People's Democratic Republic, Myanmar, Thailand, Vietnam and the People's Republic of China (Yunnan and Guangxi). With world heritage sites and a diversity of tourist attractions and cultures, this region attracts tourists from worldwide and it is expanding constantly. Partial expansion is the result of tourism promotion policy (Asian Development Bank, 2005), which is "Mekong Brand Tourism", which focuses on tourism in the GMS by emphasizing economic integration between countries in the region, especially in regard to tourism. This has been done with the support of concerned governments and aid from ADB in 1992, and included the six member countries, aiming to promote better international economic relations. Therefore, the GMS has become one of the tourism regions for which tourism promotion is required (Nonthapot, 2014; Nonthapot \& Srichaiyo, 2017). The World Travel and Tourism Council (2018) reported on the tourism situation in the Greater Mekong Sub-Region during 2012-2017 and found that large numbers of foreign tourists traveled to the GMS and expansion continues. Consequently, there was rapid growth in tourism leading to fast growing of economies in the region. During 2012-2017, the average growth in GDP in the tourism sectors of Thailand and Laos was higher than $10 \%$ while that of Cambodia was $32 \%$. The average growth in the GDP of the tourism sector in the GMS was 16.1\%. The Travel \& Tourism Competitiveness Index (TTCI)'s 2017 ranking showed that the competitiveness of Thailand and Vietnam in tourism was $34^{\text {th }}$ and $67^{\text {th }}$ in the rankings, respectively (The World Economic Forum, 2018). Furthermore, the European Council on Tourism and Trade (ECTT) announced that Cambodia was announced as the World Best Tourism Destination 2016 (European Journal of Tourism and Trade, 2016). These indicators indicate the tourism potential of GMS to travelers worldwide. Table 1 shows that $54.3 \%$ of the demand for tourism in the Greater Mekong Sub-Region is based on rankings by 53 million foreign tourists who had traveled to the GMS. The Mekong Tourism Coordinating Office (2018) reported that China was the country spending the most on tourism and $8 \%$ of the tourists to the GMS were Chinese. Other main markets were Malaysia, Korea, Japan, and the USA. According to the international tourism market share shown in

* Corresponding author

E-mail address: sakkno@kku.ac.th (S. Nonthapot)

(C) 2020 by the authors; licensee Growing Science, Canada. doi: $10.5267 /$ j.dsl.2020.9.001 
Fig. 1, (the market share of tourists traveling to the GMS in 2016) Thailand was the main destination of foreign tourists with a 54\% market share, followed by Vietnam with a 17\% market share (Mekong Tourism Coordinating Office, 2018).

Table 1

The rankings of foreign tourists who traveled to the Greater Mekong Sub-Region in 2016

\begin{tabular}{clrr}
\hline Order & Country & Number of arrivals & Total arrivals (\%) \\
\hline 1 & China & $13,013,876$ & 7.9 \\
2 & Malaysia & $4,123,629$ & 7.8 \\
3 & Korea & $3,602,934$ & 7.1 \\
4 & Japan & $2,521,654$ & 6.9 \\
5 & USA & $1,901,541$ & 4.7 \\
\hline Total & & $25,163,634$ & 54.3 \\
\hline
\end{tabular}

Source: Mekong Tourism Coordinating Office (2018)

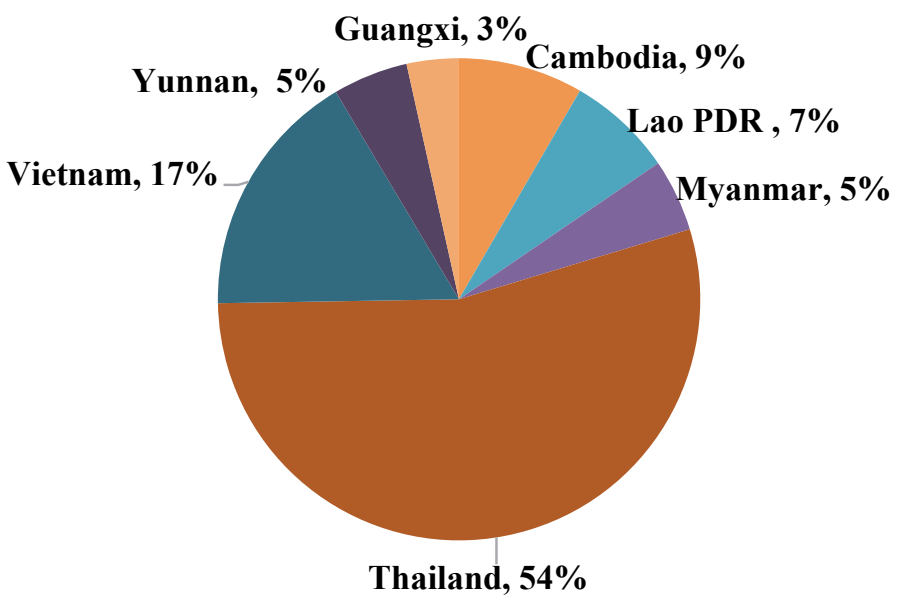

Source: Mekong Tourism Coordinating Office (2018)

Fig. 1. Market share of foreign tourists traveling to Greater Mekong Sub-Region in 2016

The tourism expansion in Greater Mekong Sub-Region indicated that the top five countries of origin for tourists were China, Malaysia, Korea, Japan, and the USA respectively. Furthermore, the tourists were also able to travel to neighboring countries. For example, Japanese tourists who visited Thailand might also travel to other countries such as Laos or Myanmar and tourists from Japan, Korea, and Malaysia entered Thailand before going to Myanmar (Nonthapot \& Lean, 2013). In addition, the travel of tourists in this region was marked by tourists traveling from one country to another adjacent country. However, there has been no study on market integration in the Greater Mekong Sub-Region based on regional relations in regard to the implementation of policy the promotion to key tourist groups or the single market policy for tourism market integration.

\section{Literature review}

Kum et al., (2015) found that incoming tourists had a positive impact on the growth of GDP. It is clear that tourism products are different from other products because tourism products cannot be verified before purchase. Thus, tourism products should be considered inclusively as it is not a single industry, but an industry group in connected tourism markets (Sinclair, et al., 2006). Furthermore, some researches did not analyze the complex factors affecting tourism, only the significant concepts and theories of economic development in the tourism industry (Stabler et al., 2010). Dwyer and Forsyth (1994); Zhang and Jensen ( 20007 ) examined foreign tourism products and found that many countries were aware that the development of tourism infrastructure was a fundamental issue in the expansion of the sector. However, to study cooperation in the tourism market in the Greater Mekong Sub-Region, Nonthapot \& Lean (2015) stated that relevant agencies should promote more transport routes, particularly air transport. In order to develop the Chinese tourist market, linked transport development for both roads and public buses is required to connect Thailand and Vietnam through Laos (Nonthapot \& Wattanakul, 2013). This supports the Theory of Relations of Activities within a Region by Hoover \& Giarratani (1999), which explains the relationships by classification into three types: first, vertical relationships which attract each other and involve two parts: 1) backward linkage and 2) forward linkage; second, horizontal relationships that involve competition in activities and similar business units, and third, complementary relationships where new activities support other activities in a specific region. Similarly, tourism supply plays a significant role in the tourism market. There has been no study of the tourism market between the countries in this region. For this reason, this research aims to examine the integration of the main foreign tourist markets in the Greater Mekong Sub-Region. This research analyzes the impact of 
foreign tourism on the countries in the GMS to determine the tourism relations between the countries in the GMS. Further, in the case of the land transport connecting the countries in the region such as international passengers, if tourists would like to travel by Hanoi-Bangkok bus, they travel with Company A and connect with a bus from Company B. Company A would issue the ticket for Company B to the tourist. Such cooperation between Company A and B is an example of informal international cooperation between the countries. Therefore, there are complementary relations within the region through international passengers (Nonthapot, et al., 2019). In addition, the research supports the concept of relations of activities within a region (Hoover \& Giarratani, 1999) and the tourism market relations should be explained by causality testing more than correlation analysis.

\section{Research methodology}

\subsection{Data and data sources}

Secondary data from 2001-2017 by quarter (17 years) were used. All data were modified into a natural logarithm as follows.

1) Data of foreign tourists from all countries, except Laos.

2) Data of foreign tourists in Laos from the Ministry of Information, Culture and Tourism.

\subsection{Unit root with Structural Break}

The Augmented Dickey-Fuller (ADF) unit root test is a common tool to test the stationarity and the order of integration of variables (Nguyen \& Le, 2020). However, Lee and Strazicich (2003) develop a two-break minimum Lagrange Multiplier (LM) unit root test in which the alternative hypothesis unambiguously implies trend stationarity. The main advantages of the minimum LM unit root test suggested by Lee \& Strazicich are as follows:

1) the break points are determined endogenously from the data;

2) the structural breaks are allowed under null and alternative hypotheses;

3) avoids the problem of bias and spurious rejections associated with previous tests;

4) the LM test enables accurate break-point estimation.

In addition, we can consider the data-generating process (DGP) and the details of the process. The critical values for the two-break case are tabulated in Lee \& Strazicich (2003).

\subsection{Lag testing with the VAR Model}

Optimal Lag Length with Akailke information Criteria (AIC) is tested to examine the suitable delay. Since the VAR model limits the appropriate time of delay which should be equal, a lag test was required before analysis. The lag that gave the least AIC would be selected. This research used AIC calculated from the following formula (Lütkepohl, 2005; Nonthapot, 2017).

$A I C=2 k-2 \ln (L)$

$L$ is the highest value in Likelihood Function of the estimation

$k$ is the number of coefficient estimation

$n$ is number of all data

\subsection{Granger Causality Test}

The relations between tourist markets in the region was conducted using Granger Causality (Granger, 1988) as per the following tourism market model:

$$
Q_{a, j, t}=\alpha_{a}+\sum_{i=1}^{p} \beta_{1 i} Q_{a, j, \mathrm{t}-1}+\sum_{i=1}^{p} \beta_{2 i} Q_{a, \mathrm{k}, \mathrm{t}-1}+\sum_{i=1}^{p} \beta_{3 i} Q_{a, \mathrm{l}, \mathrm{t}-1}+\sum_{i=1}^{p} \beta_{4 i} Q_{a, \mathrm{~m}, \mathrm{t}-1}+\sum_{i=1}^{p} \beta_{5 i} Q_{a, \mathrm{n}, \mathrm{t}-1}+\varepsilon_{a, t}
$$

where:

$\mathrm{Q}_{\mathrm{a}}$ is the number of tourists from home country (a) traveling from country a to countries $\mathrm{j}, \mathrm{k}, 1, \mathrm{~m}$ and $\mathrm{n}$ at time $\mathrm{t}$

$\mathrm{a}$ is China, Malaysia, Korea, Japan, and the USA

$\mathrm{j}, \mathrm{k}, \mathrm{l}, \mathrm{m}$ and $\mathrm{n}$ is Cambodia, Laos, Myanmar, Thailand, and Vietnam

under the condition of $\mathrm{j} \neq \mathrm{k} \neq \mathrm{l} \neq \mathrm{m} \neq \mathrm{n}$

$i$ is the number of lags

If $\beta_{2}-\beta_{5} \neq 0, Q_{a, \mathrm{k}, \mathrm{t}-1}, Q_{a, 1, \mathrm{t}-1}, Q_{a, \mathrm{~m}, \mathrm{t}-1}, Q_{a, \mathrm{n}, \mathrm{t}-1}$ was the cause of $Q_{a, j, t}$

If $\beta_{2}-\beta_{5}=0, Q_{a, \mathrm{k}, \mathrm{t}-1}, Q_{a, 1, \mathrm{t}-1}, Q_{a, \mathrm{~m}, \mathrm{t}-1}, Q_{a, \mathrm{n}, \mathrm{t}-1}$ was not the cause of $Q_{a, j, t}$ 
The next step after we get the results from causality test is to focus on the relation concept and make anchors between the relationships in each tourist market of country a.

\subsection{Constructing relations between the variables based on the regional economic activity relations concept}

With the results of relations between tourist markets, this study imply from the regional economic activity relations concept to international tourist market concept in the GMS (a region). The relations are interpreted from the Granger Causality test results (Topic 3.4). The figures of five tourist market relations can be created in three types: horizontal, vertical, and complementary relationships as shown in Figures 2 - 4

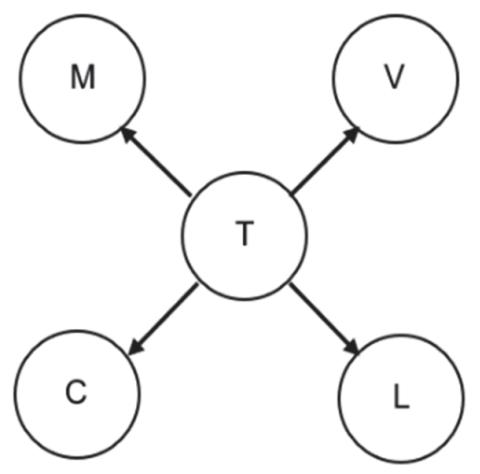

(a)

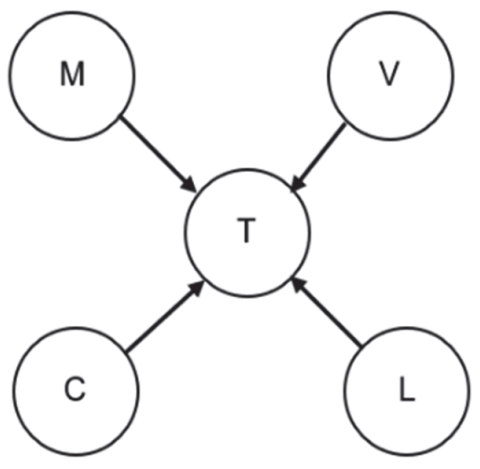

(b)

Fig. 2. Horizontal relationships

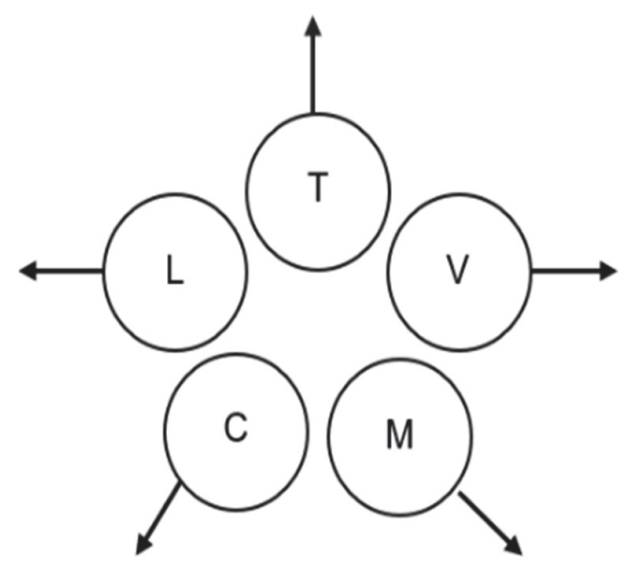

Fig. 3. Vertical Relationships

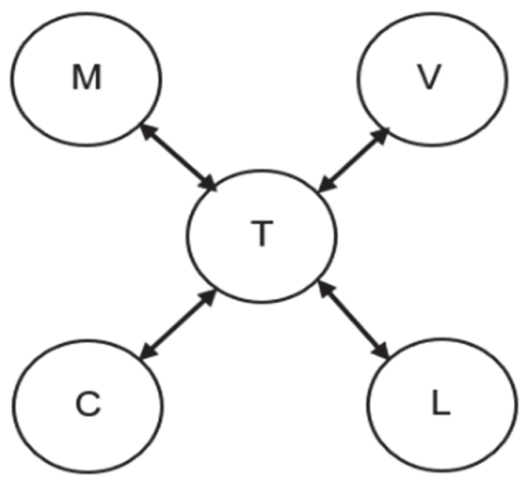

Fig. 4. Complementary Relationships 


\section{Results}

\subsection{Unit Root Test with Structural Break}

Table 2 shows the results of the Unit Root Test with Structural Break by Lee and Strazicich (2003). Considering the value for LS1 or Time break 1, the critical value changed from -4.45 to 4.51 according to the position of one break $\lambda(=\mathrm{TB} / \mathrm{T})$ considering the value of Lee and Strazicich (2003). LS2 test or Time break 2 of the critical time changed from -5.59 to 5.74 according to the position of two breaks $\lambda 1(=\mathrm{TB} 1 / \mathrm{T})$ and $\lambda 2(=\mathrm{TB} 2 / \mathrm{T})$ as shown in Table 2 (Lee and Strazicich 2003). The table reveals that all 25 variables had stationarity at I (0) with statistical significance at 0.05 as it accepted the main hypothesis that all variables displayed stationarity properties. This led to the test of the Vector Autoregressive (VARs) model and the test of interdependence using Granger Causality Test (Granger, 1998).

Table 2

Unit Root results with two structural Breaks

\begin{tabular}{|c|c|c|c|c|}
\hline \multirow{2}{*}{ Market } & \multirow{2}{*}{ Variables } & \multicolumn{2}{|c|}{ tau - statistics } & \multirow{2}{*}{ Order of Stationary } \\
\hline & & LS1 & LS2 & \\
\hline \multirow{5}{*}{ China } & $\mathrm{Q}_{\mathrm{C}}$ & $-4.67(8)[2012 \mathrm{Q} 4]^{* *}$ & $-9.57(5)[2010 \mathrm{Q} 1,2015 \mathrm{Q} 4]^{* * *}$ & $\mathrm{I}(0)$ \\
\hline & $\mathrm{Q}_{\mathrm{L}}$ & $-5.65(8)[2014 \mathrm{Q} 3]^{* * *}$ & $-7.76(8)[2008 \mathrm{Q} 4,2014 \mathrm{Q} 3]^{* * *}$ & $\mathrm{I}(0)$ \\
\hline & $\mathrm{Q}_{\mathrm{M}}$ & $-4.23(8)[2013 \mathrm{Q} 3]^{*}$ & $-6.18(4)[2008 \mathrm{Q} 2,2014 \mathrm{Q} 2]^{* *}$ & $\mathrm{I}(0)$ \\
\hline & $\mathrm{Q}_{\mathrm{T}}$ & $-4.84(4)[2011 \mathrm{Q} 3]^{* *}$ & $-7.78(2)[2009 Q 4,2014 Q 4]^{* * *}$ & $\mathrm{I}(0)$ \\
\hline & $\mathrm{Q}_{\mathrm{v}}$ & $-5.64(8)[2013 \mathrm{Q} 2]^{* * *}$ & $-7.76(1)[2008 \mathrm{Q} 1,2013 \mathrm{Q} 3]^{* * *}$ & $\mathrm{I}(0)$ \\
\hline \multirow{5}{*}{ Japan } & $\mathrm{Q}_{\mathrm{C}}$ & $-5.27(6)[2008 \mathrm{Q} 3]^{* * *}$ & $-6.07(7)[2008 \mathrm{Q} 2,2013 \mathrm{Q} 3]^{*}$ & $\mathrm{I}(0)$ \\
\hline & $\mathrm{Q}_{\mathrm{L}}$ & $-5.79(8)[2012 \mathrm{Q} 4]^{* * *}$ & $-8.99(8)[2012 \mathrm{Q} 4,2016 \mathrm{Q} 1]^{* * *}$ & $\mathrm{I}(0)$ \\
\hline & $\mathrm{Q}_{\mathrm{M}}$ & $-4.07(8)[2007 \mathrm{Q} 2]^{*}$ & $-6.52(8)[2007 \mathrm{Q} 2,2011 \mathrm{Q} 4]^{* *}$ & $\mathrm{I}(0)$ \\
\hline & $\mathrm{Q}_{\mathrm{T}}$ & $-4.98(8)[2011 \mathrm{Q} 3]^{* * *}$ & $-5.20(4)[2007 \mathrm{Q} 1,2011 \mathrm{Q} 2]$ & $\mathrm{I}(0)$ \\
\hline & $\mathrm{Q}_{\mathrm{V}}$ & $-5.26(8)[2007 \mathrm{Q} 3]^{* * *}$ & $-8.48(8)[2006 \mathrm{Q} 4,2007 \mathrm{Q} 3]^{* * *}$ & $\mathrm{I}(0)$ \\
\hline \multirow{5}{*}{ Korea } & $\mathrm{Q}_{\mathrm{C}}$ & $-4.46(8)[2005 \mathrm{Q} 1]^{* *}$ & $-5.31(6)[2006 \mathrm{Q} 1,2011 \mathrm{Q} 3]$ & $\mathrm{I}(0)$ \\
\hline & $\mathrm{Q}_{\mathrm{L}}$ & $-5.21(5)[2012 \mathrm{Q} 4]^{* * *}$ & $-6.78(5)[2012 \mathrm{Q} 4,2015 \mathrm{Q} 3]^{* *}$ & $\mathrm{I}(0)$ \\
\hline & $Q_{M}$ & $-4.90(5)[2012 \mathrm{Q} 3]^{* * *}$ & $-7.53(5)[2008 \mathrm{Q} 3,2012 \mathrm{Q} 3]^{* * *}$ & $\mathrm{I}(0)$ \\
\hline & $\mathrm{Q}_{\mathrm{T}}$ & $-3.67(4)[2007 \mathrm{Q} 1]^{* *}$ & $-5.81(8)[2004 \mathrm{Q} 4,2008 \mathrm{Q} 2]^{*}$ & $\mathrm{I}(0)$ \\
\hline & $\mathrm{Q}_{\mathrm{V}}$ & $-5.69(7)[2014 \mathrm{Q} 2]^{* * *}$ & $-6.98(5)[2013 \mathrm{Q} 2,2015 \mathrm{Q} 3]^{* * *}$ & $\mathrm{I}(0)$ \\
\hline \multirow{5}{*}{ Malaysia } & $\mathrm{Q}_{\mathrm{C}}$ & $-4.95(5)[2015 \mathrm{Q} 2]^{* * *}$ & $-5.42(6)[2005 \mathrm{Q} 3,2015 \mathrm{Q} 1]$ & $\mathrm{I}(0)$ \\
\hline & $\mathrm{Q}_{\mathrm{L}}$ & $-5.63(4)[2012 \mathrm{Q} 3]^{* * *}$ & $-6.14(4)[2006 \mathrm{Q} 3,2012 \mathrm{Q} 3]^{*}$ & $\mathrm{I}(0)$ \\
\hline & $\mathrm{Q}_{\mathrm{M}}$ & $-5.19(0)[2010 \mathrm{Q} 2]^{* * *}$ & $-7.02(0)[2008 \mathrm{Q} 2,2012 \mathrm{Q} 3]^{* * *}$ & $\mathrm{I}(0)$ \\
\hline & $\mathrm{Q}_{\mathrm{T}}$ & $-5.89(4)[2010 \mathrm{Q} 2]^{* * *}$ & $-6.68(4)[2009 \mathrm{Q} 3,2015 \mathrm{Q} 3]^{* *}$ & $\mathrm{I}(0)$ \\
\hline & $\mathrm{QV}_{\mathrm{V}}$ & $-5.64(8)[2013 \mathrm{Q} 3]^{* * *}$ & $-8.96(7)[2011 \mathrm{Q} 4,2012 \mathrm{Q} 3]^{* * *}$ & $\mathrm{I}(0)$ \\
\hline \multirow{5}{*}{ USA } & $\mathrm{Q}_{\mathrm{C}}$ & $-5.98(8)[2016 \mathrm{Q} 1]^{* * *}$ & $-4.95(5)[2005 \mathrm{Q} 1,2008 \mathrm{Q} 1$ & $\mathrm{I}(0)$ \\
\hline & $\mathrm{Q}_{\mathrm{L}}$ & $-4.44(4)[2013 \mathrm{Q} 2]^{* *}$ & $-5.69(4)[2009 \mathrm{Q} 1,2013 \mathrm{Q} 3]$ & $\mathrm{I}(0)$ \\
\hline & $\mathrm{Q}_{\mathrm{M}}$ & $-15.52(1)[2011 \mathrm{Q} 2]^{* * *}$ & $-18.73(1) 2008 \mathrm{Q} 2,2012 \mathrm{Q} 1]^{* * *}$ & $\mathrm{I}(0)$ \\
\hline & $\mathrm{Q}_{\mathrm{T}}$ & $-4.49(8)[2012 \mathrm{Q} 3]^{* *}$ & $-5.46(8)[2010 \mathrm{Q} 1,2013 \mathrm{Q} 3]$ & $\mathrm{I}(0)$ \\
\hline & $\mathrm{Q}_{\mathrm{V}}$ & $-4.15(8)[2012 \mathrm{Q} 2]^{*}$ & $-8.81(7)[2006 \mathrm{Q} 4,2007 \mathrm{Q} 3]^{* * *}$ & $\mathrm{I}(0)$ \\
\hline
\end{tabular}

Source: From calculation

Note: C, L, M, T, V is Cambodia, Laos, Myanmar, Thailand and Vietnam tourist markets respectively

Number of lags, $\mathrm{k}$, and break points, TB, in ( ) and [ ]

$*, * *, * * *$ significance at the level $0.1,0.05$ and 0.01

\subsection{Determining the number of Lags for the VAR model using Information Criteria}

The result of Optimal Lags Length Criteria testing using Akaike information criterion (AIC) with the group of Chinese, Japanese, and Malaysian tourists indicated that the appropriate number of lags was 8 . The lag in the Korean tourist group was 7 and that for American tourists was 6. Therefore, the Lag Length was used in the model and in relations estimation in the next process.

\subsection{Causality test using Granger Causality Test}

The Granger Causality test result for the Chinese tourists group presented in Table 3 reveals that the number of Chinese tourists in Thailand was related to the number of Chinese tourists in Cambodia whereas the number of Chinese tourists in Laos was related to the number of Chinese tourists in Thailand with confidence at $95 \%$. In addition, the number of Chinese tourists in Cambodia was related to the number of Chinese tourists in Laos while the number of Chinese tourists in Cambodia, Laos, Myanmar, and Thailand was related to the number of Chinese tourists in Vietnam with confidence at $99 \%$. In the Japanese tourist market, it was found that the number of Japanese tourists in Thailand and Vietnam was related to number of Japanese tourists in Laos whereas the number of Japanese tourists in Laos and Vietnam was related to the number of Japanese tourists in Myanmar with confidence at 99\%. Furthermore, the number of Japanese tourists in Cambodia was related to the number of Japanese tourists in Myanmar with confidence 95\%. For Korean tourist market, the number of Korean tourists in Cambodia, Myanmar, and Vietnam was related to the number of Korean tourists in Laos. Similarly, the number of Korean tourists in Laos was related to that in Myanmar while the number of Korean tourists in Myanmar was related to the number of Korean tourists in Vietnam with confidence at $99 \%$. Furthermore, the number of Korean tourists in Thailand and Vietnam was related to the number of Chinese tourists in Myanmar with confidence at 95\%. For the Malaysian tourist market, the number of Malaysian tourists in Vietnam was related to the number of Malaysian tourists in Cambodia, Laos, and Myanmar whereas 
the number of Malaysian tourists in Cambodia was related to the number of Malaysian tourists in Myanmar. In addition, the number of Malaysian tourist in Myanmar was related to the number of Malaysian tourists in Vietnam with confidence at $95 \%$. Furthermore, the number of Malaysian tourists in Vietnam was related to the number of Malaysian tourists in Thailand whereas the number of Malaysian tourists in Cambodia and Thailand was related to the number in Vietnam with confidence at 99\%. Lastly, in the American tourist market, the number of American tourists in Cambodia was related to the number of American tourists in Lao while the number of American tourists in Laos was related to that in Thailand. The number of American tourists in Cambodia was related to the number in Vietnam with confidence at $95 \%$. In addition, the number of American tourists in Cambodia, Myanmar, and Vietnam was related to the number in Thailand while the number of American tourists in Myanmar and Thailand was related to the number in Vietnam with confidence at $99 \%$.

Table 3

The test results on the relationship properties of the VAR model

\begin{tabular}{|c|c|c|c|c|c|c|}
\hline \multirow[t]{2}{*}{$\begin{array}{l}\text { Tourist } \\
\text { market }\end{array}$} & \multirow[t]{2}{*}{ Dependent } & \multicolumn{5}{|c|}{$\begin{array}{l}\text { Independent } \\
\chi^{2} \text {-statistics }\end{array}$} \\
\hline & & $\mathrm{Q}_{\mathrm{C}}$ & $\mathrm{Q}_{\mathrm{L}}$ & $\mathrm{Q}_{\mathrm{M}}$ & $\mathrm{Q}_{\mathrm{T}}$ & $\mathrm{Q}_{\mathrm{v}}$ \\
\hline \multirow{5}{*}{ Chinese tourists } & $\mathrm{Q}_{\mathrm{c}}$ & - & $16.371 * *[8]$ & $9.347[8]$ & $8.658[8]$ & $12.663[8]$ \\
\hline & $\mathrm{Q}_{\mathrm{L}}$ & $25.479 * * *[8]$ & {$[1]$} & $7.263[8]$ & $14.001[8]$ & $10.249[8]$ \\
\hline & $\mathrm{Q}_{\mathrm{M}}$ & $8.723[8]$ & $4.597[8]$ & - & $7.023[8]$ & $7.749[8]$ \\
\hline & $\mathrm{Q}_{\mathrm{T}}$ & $7.085[8]$ & $16.239 * *[8]$ & $2.476[8]$ & - & $13.741[8]$ \\
\hline & $\mathrm{Q}_{\mathrm{v}}$ & $29.548^{* * *}[8]$ & $32.135 * * *[8]$ & $26.069 * * *[8]$ & $24.233 * * *[8]$ & - \\
\hline \multirow{6}{*}{ Japanese tourists } & & $\mathrm{Q}_{\mathrm{C}}$ & $\mathrm{Q}_{\mathrm{L}}$ & $\mathrm{Q}_{\mathrm{M}}$ & $\mathrm{Q}_{\mathrm{T}}$ & $\mathrm{Q}_{\mathrm{v}}$ \\
\hline & $\mathrm{Q}_{\mathrm{C}}$ & - & $4.208[8]$ & $6.247[8]$ & $8.705[8]$ & $9.041[8]$ \\
\hline & $\mathrm{Q}_{\mathrm{L}}$ & $12.199[8]$ & - & $8.982[8]$ & $24.159 * * *[8]$ & $21.092 * * *[8]$ \\
\hline & $\mathrm{Q}_{\mathrm{M}}$ & $17.757 * *[8]$ & $20.171^{* * *}[8]$ & - & $13.782[8]$ & $24.120 * * *[8]$ \\
\hline & $\mathrm{Q}_{\mathrm{T}}$ & $11.003[8]$ & $9.018[8]$ & $8.142[8]$ & - & $15.255[8]$ \\
\hline & $\mathrm{Q}_{\mathrm{V}}$ & $6.705[8]$ & $1.755[8]$ & $5.767[8]$ & $5.030[8]$ & - \\
\hline \multirow{6}{*}{ Korean tourists } & & $\mathrm{Q}_{\mathrm{C}}$ & $\mathrm{Q}_{\mathrm{L}}$ & $\mathrm{Q}_{\mathrm{M}}$ & $\mathrm{Q}_{\mathrm{T}}$ & $\mathrm{Q}_{\mathrm{v}}$ \\
\hline & $\mathrm{Q}_{\mathrm{C}}$ & - & $5.245[7]$ & $7.662[7]$ & $3.119[7]$ & $11.122[7]$ \\
\hline & $\mathrm{Q}_{\mathrm{L}}$ & $38.896^{* * *[7]}$ & - & $46.968 * * *[7]$ & $12.925[7]$ & $77.743 * * *[7]$ \\
\hline & $\mathrm{Q}_{\mathrm{M}}$ & $4.638[7]$ & $19.587^{* * *[7]}$ & - & $14.176^{* *}[7]$ & $14.844 * *[7]$ \\
\hline & $\mathrm{Q}_{\mathrm{T}}$ & $2.580[7]$ & $3.439[7]$ & $4.026[7]$ & - & $2.331[7]$ \\
\hline & $\mathrm{Q}_{\mathrm{v}}$ & $10.763[7]$ & $5.761[7]$ & $15.487 * * *[7]$ & $3.363[7]$ & - \\
\hline \multirow{6}{*}{ Malaysian tourists } & & $\mathrm{Q}_{\mathrm{C}}$ & $\mathrm{Q}_{\mathrm{L}}$ & $\mathrm{Q}_{\mathrm{M}}$ & $\mathrm{Q}_{\mathrm{T}}$ & Qv \\
\hline & $\mathrm{Q}_{\mathrm{C}}$ & - & $2.532[8]$ & $11.279[8]$ & $5.568[8]$ & $16.692 * *[8]$ \\
\hline & $\mathrm{Q}_{\mathrm{L}}$ & $14.742[8]$ & - & $11.355[8]$ & $8.077[8]$ & $16.555 * *[8]$ \\
\hline & $\mathrm{Q}_{\mathrm{M}}$ & $15.973 * *[8]$ & $7.031[8]$ & - & $8.883[8]$ & $17.103 * *[8]$ \\
\hline & $\mathrm{Q}_{\mathrm{T}}$ & $14.119[8]$ & $7.079[8]$ & $12.325[8]$ & - & $22.857 * * *[8]$ \\
\hline & $\mathrm{Q}_{\mathrm{v}}$ & $21.924 * * *[8]$ & $8.969[8]$ & $17.724 * *[8]$ & $44.231 * * *[8]$ & - \\
\hline \multirow{6}{*}{ USA tourists } & & $\mathbf{Q c}_{\mathrm{C}}$ & $\mathbf{Q}_{\mathrm{L}}$ & $\mathbf{Q}_{\mathbf{M}}$ & $\mathbf{Q}_{\mathrm{T}}$ & $\mathbf{Q v}_{\mathrm{v}}$ \\
\hline & $\mathrm{Q}_{\mathrm{C}}$ & - & $2.718[6]$ & $9.146[6]$ & $1.524[6]$ & $10.469[6]$ \\
\hline & $\mathrm{Q}_{\mathrm{L}}$ & $15.832 * *[6]$ & - & $7.226[6]$ & $9.459[6]$ & $5.875[6]$ \\
\hline & $\mathrm{Q}_{M}$ & $6.015[6]$ & $7.861[6]$ & - & $4.542[6]$ & $1.271[6]$ \\
\hline & $\mathrm{Q}_{\mathrm{T}}$ & $20.698 * * *[6]$ & $12.597^{* *}[6]$ & $19.418 * * *[6]$ & - & $31.945 * * *[6]$ \\
\hline & $\mathrm{Q}_{\mathrm{v}}$ & $16.295^{* *}[6]$ & $3.969[6]$ & $22.486 * * *[6]$ & $20.784 * * *[6]$ & - \\
\hline
\end{tabular}

Source: From calculation

Note: [ ] lags selection, ** Confidence level $95 \%$ and $* * *$ Confidence level $99 \%$

C, L, M, T, V is Cambodia, Laos, Myanmar, Thailand and Vietnam tourist markets respectively

\subsubsection{Constructing relationships between tourism markets in the Greater Mekong Sub-Region}

\section{1) Chinese tourist market}

Fig. 5 shows the relationships of Chinese tourists traveling to GMS. The causality test indicated that the travel of Chinese tourists to any country in the GMS, particularly to Myanmar, Laos, and Cambodia led to forward relations with Vietnam. Thailand and Cambodia were the countries transferring Chinese tourists from Laos to Vietnam. Furthermore, the relationship between Chinese tourists in Laos and Cambodia was found to be complementary.

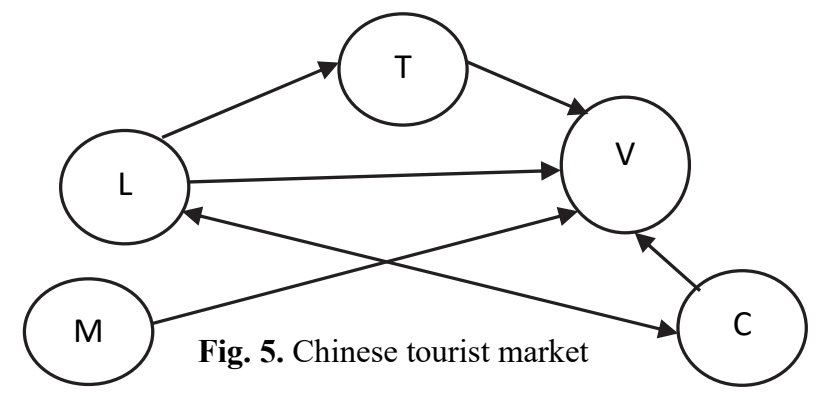




\section{2) Japanese tourist market}

Fig. 6 shows the relationships of Japanese tourists traveling to the GMS. The causality test revealed that the travel behavior of Japanese tourists traveling to any country in the GMS, particularly Thailand, Vietnam, and Cambodia led to forward relations with Myanmar. Laos transfers Japanese tourists from Thailand and Vietnam to Myanmar.

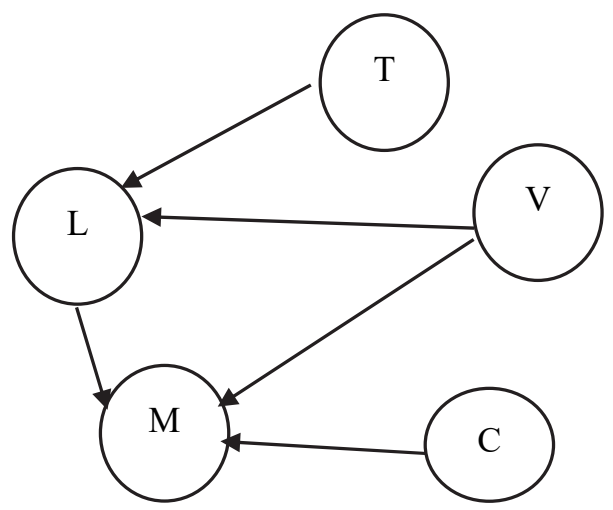

Fig. 6. Japanese tourist market

\section{3) Korean tourist market}

Fig.7 shows the relationships of Korean tourists traveling to the GMS. The causality test revealed that the travel behavior of Korean tourists traveling to any country in the GMS, particularly Thailand, Cambodia, and Vietnam led to forward relations with Laos and Myanmar. In addition, the relationship between Korean tourists in Laos and Myanmar and Korean tourists in Myanmar and Vietnam was found to be complementary.

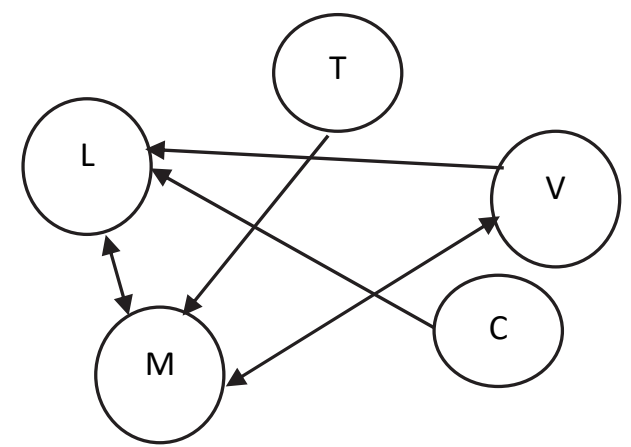

Fig. 7. Korean tourist market

\section{4) Malaysian tourist market}

Fig. 8 shows the relationships of Malaysian tourists traveling to the GMS. The causality test revealed that the travel behavior of Malaysian tourists traveling to any country in the GMS was complementary. That is to say, the Malaysian tourist market in Thailand has a complementary relationship with the Malaysian tourist market in Vietnam. The Malaysian tourist market in Vietnam had complementary relations with that in Cambodia. The Malaysian tourist market in Vietnam had complementary relations with that in Myanmar. In addition, it is noticeable that when the Malaysian tourist market in Vietnam had forward relations with Laos, the Malaysian tourist market in Cambodia also had forward relations with Malaysian tourists in Myanmar.

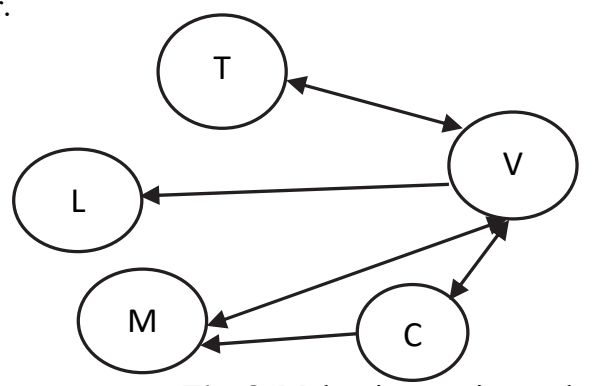

Fig. 8. Malaysian tourist market 


\section{5) American tourist market}

The relationships of American tourists traveling to the GMS are shown in Fig. 9. It was found that the travel behavior of American tourists traveling to any country in the GMS, particularly Myanmar and Cambodia led to forward relations with Thailand and Vietnam. Laos transfers tourists from Cambodia to Thailand while Vietnam transfers tourists from Myanmar and Cambodia to Thailand. The American tourist markets in Myanmar and Cambodia had forward relations with that of Thailand. The American tourist market in Thailand and Vietnam was found to be complementary.

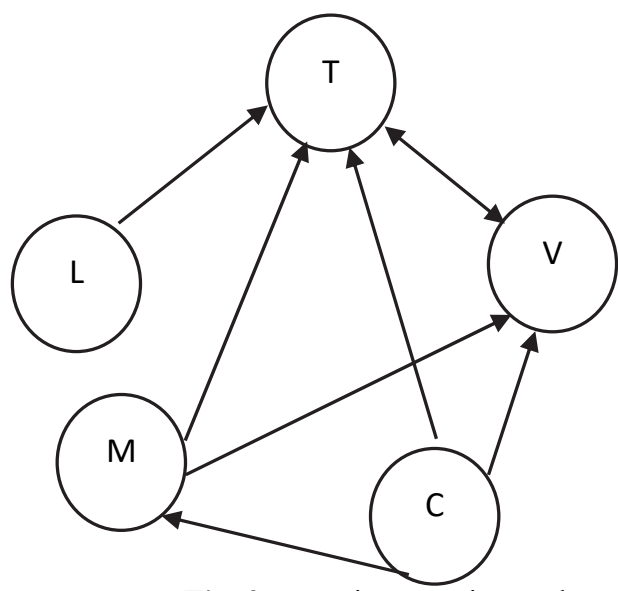

Fig. 9. American tourist market

\section{Conclusion and Discussion}

The objectives of this research were to examine the relations of the main international tourist markets in the Greater Mekong Sub-Region and to analyze the data using the Vector Autoregressive (VAR) model to test the Granger Causality to explain the relationships between tourist markets in the region. The findings revealed that the main tourist markets of the GMS in Cambodia had forward relations with Laos and Vietnam. The main tourist markets of the GMS in Laos had forward relations with Myanmar and Thailand. The main tourist market of the GMS in Myanmar had forward relations with Vietnam, Laos, and Thailand. Furthermore, the main tourist markets in Thailand had forward relations with Vietnam, Laos, and Myanmar whereas the main market in Vietnam had forward relations with Laos, Myanmar, Thailand, and Cambodia. However, each country is an entry point to other countries which reflects the complementary relationships between the tourist markets in the GMS. Vietnam is the country that was found to have the most links with other countries.

When considering the integration of the main foreign tourist markets of the GMS, involving Cambodia, Laos, Myanmar, Thailand, and Vietnam, it was found out that the tourist markets in Cambodia had forward relations with Laos and Vietnam. The tourist markets in Laos had forward relations with Myanmar and Thailand. The tourist markets of Myanmar had forward relations with Vietnam, Laos, and Thailand. The tourist markets in Thailand had forward relations with Vietnam, Laos, and Myanmar. The tourist markets in Vietnam had forward relations with Laos, Myanmar, Thailand, and Cambodia. This is in line with Forward Linkage theory; the forward transfer of the tourism process between two countries which support tourism activities to fulfill tourist demand. Considering the overview of the main foreign tourist markets of the Greater Mekong Sub-Region which had complementary relations, it was found that Vietnam connected with other countries the most. This is consistent with the Complementary Relationships concept; mutual attraction among regional tourism markets with complementary destinations. In addition, it is also consistent with the study of Nonthapot \& Wattanakul (2013) which reported that the tourism markets of Thailand and Laos was a mutual market for Chinese tourists.

Based on the research findings, there are recommendations for government and private sector of each country in the GMS, including relevant agencies, to apply tourism development policy in the GMS as follows.

1. The governments, private sector and relevant agencies of all countries in the GMS should cooperate in tourism promotion in the GMS and among Cambodia, Laos, Myanmar, Vietnam and Thailand (CLMVT). For example, the development of market and tourism focusing on providing convenience through a campaign promoting tourist sites or culture such as Buddhism in the Greater Mekong Sub-Region, cuisine in the Greater Mekong Sub-Region should be initiated. Furthermore, tourism programs between CLMVT may be initiated as 18 World Heritage sites are located in this region; 8 in Vietnam, 5 in Thailand, 2 in Laos, 2 in Cambodia, and one in Myanmar. With this advantage, tourists will be able to travel across the countries in the GMS with fewer barriers or delays.

2. The government, the private sector and relevant agencies of each country in the GMS should develop advanced and fast transportation to facilitate tourism in GMS countries, for example, the development of land transport in the GMS countries such as the China-Laos high-speed train, which would allow the tourist market to be more connected. The expansion of air transport should also be considered. It can be seen that Vietjet Air shares the business with Thailand to open new routes in 
order to expand the tourist market within and between the regions, and to allow the integration of tourist market in the GMS. In addition, the development of border crossing points should also be considered. For example, various crossing points should be established, especially on routes that take time to travel, such as traveling from Ha Tian Border to Phu Quoc Island, which normally takes more than 8 hours. If there is a border crossing at Kep Town in Cambodia, it would take only 20 minutes by boat. It is the same in the case of the Langkawi Island (Malaysia) - Koh Lipe Island (Thailand) checkpoint. This problem demonstrates the loss of opportunity to increase the number of tourists in the GMS.

3. The government sector of each country in the GMS should implement policy to allow foreign tourists to travel to the countries in the GMS with a single visa for all member countries as a common market under the policy to promote a single market.

\section{References}

Asian Development Bank. (2005). The Greater Mekong Sub-region tourism sector strategy. Asian Development Bank, Manila, Philippines.

Dwyer, L., \& Forsyth, P. (1994). Foreign tourism investment: Motivation and impact. Annals of Tourism Research, 21(3), $512-537$.

European Journal of tourism and trade (2016). World Tourism day 2017 Celebrated in Cambodia.

Granger, C.W.J. (1988). Some recent development in a concept of causality. Journal of Econometrics, 39, $199-211$.

Hoover, E. M. \& Giarratani, F. (1999). An Introduction to Regional Economics, $4^{\text {th }}$ ed. Newyork: Alfred A. Knopf, Inc.

Kum, H., Aslan, A., \& Gungor, M. (2015). Tourism and Economic Growth: The case of Next 11 Countries. International Journal of Economics and Financial Issues, 5 (4), 1075-1081.

Lee, J. \& Strazicich, M.C. (2003). Minimum lagrange multiplier unit root test with two structural breaks. Review of Economics and Statistics, 85(4), 1082-1089.

Lütkepohl, H. (2005). New Introduction to Multiple Time Series Analysis, Berlin:.Springer-Verlag,

Mekong Tourism Coordinating office. (2018). Tourism statistics.

Nguyen, T., \& Le, Q. (2020). Impact of globalization on CO2 emissions in Vietnam: An autoregressive distributed lag approach. Decision Science Letters, 9(2), 257-270.

Nonthapot, S. \& Lean, H. H. (2013). Demand of Thai Tourists to Lao PDR: An ARDL Approach. Asian Journal of Empirical Research, Asian Economic and Social Society, 3(3), 279-285.

Nonthapot, S., \& Lean, H. H. (2015). International tourism market analysis in the Greater Mekong Sub-Region: A panel data approach. Pertanika Journal of Social Sciences and Humanities. 23 (4), 945-966.

Nonthapot, S. \& Wattanakul, T. (2013). Demand regional tourists visiting Lao People's democratic republic: A dynamic panel data approach. Journal of Environmental Management and Tourism, 4(1), 21-28.

Nonthapot, S. (2014). The relationship between tourism and economic development in the greater Mekong Sub-region: Panel Cointegration and Granger Causality. Journal of Advanced Research in Law and Economics, 5(1), 44-51.

Nonthapot, S. (2017). Causality between capital investment in the tourism sector and tourist arrivals in ASEAN. Journal of Advanced Research in Law and Economics, 8(8), 2504-2511.

Nonthapot, S. \& Srichaiyo, P. (2017). The Effects of Financial Crises on Tourism in the Greater Mekong Sub-region: Panel ARDL approach. Journal of Environmental Management and Tourism, 8(4), 853-860.

Nonthapot, S., Dinh, T.N., \& Thuan, Y.T. (2019). The process of land passenger transportation by international bus crossing Lao and Vietnamese border gates.The Open Transportation Journal, 13, 1-10.

Sinclair, M. T., Blake, A., \& Sugiyarto, G. (2006). Classic reviews in tourism. New Delhi: Vivabooks Private Limited.

Stabler, M. J., Papatheororou, A., \& Sinclair, M. T. (2010). The economics of tourism, $2^{\text {nd }}$ Ed. New York: Routledge Press. The World Economic Forum. (2018). the Travel \& Tourism Competitiveness Report 2017.

World Travel and Tourism Council. (2018). Total contribution to GDP.

Zhang, J., \& Jensen, C. (2007). Comparative advantage explaining tourism flows. Annals of Tourism Research, 34(1), 223243. 
C 2020 by the authors; licensee Growing Science, Canada. This is an open access article distributed under the terms and conditions of the Creative Commons Attribution (CC-BY) license (http://creativecommons.org/licenses/by/4.0/). 